\title{
Cellular and molecular responses of adult testis to changes in nutrition: novel insights from the sheep model
}

\author{
Yongjuan Guan ${ }^{\dagger}$ and Graeme B Martin \\ UWA Institute of Agriculture and School of Agriculture and Environment M087, University of Western Australia, \\ Crawley, Australia \\ Correspondence should be addressed to G B Martin; Email: graeme.martin@uwa.edu.au \\ ${ }^{\dagger}(Y$ Guan is now at Department of Biomedical Sciences, School of Veterinary Sciences, University of Pennsylvania, Philadelphia, \\ Pennsylvania, USA)
}

\begin{abstract}
This review explores the cellular and molecular mechanisms that regulate spermatogenesis in the post-pubertal testis that is regressing in response to mild undernutrition, using the sexually mature male sheep as a model. Testis regression leads to reductions in daily sperm production and in the quality of ejaculated spermatozoa (poorer movement, DNA damage). There is also a reduction in spermatogenic efficiency that appears to be caused, at least partially, by increases in germ cell apoptosis. Sertoli cell number does not change with testis regression, although about $1 \%$ of Sertoli cells do appear to retain proliferative ability after puberty. On the other hand, Sertoli cell function is disrupted during testis regression, as evidenced by a disorganization of tight junctions and indications that cell differentiation and maturation are reversed. Disrupted Sertoli cell function can explain, at least partially, the increase in germ cell apoptosis and any decrease in the rate of spermatogenesis, the two major contributors to spermatogenic efficiency. These outcomes seem to be mediated by changes in two RNA-based processes: (i) the expression of small non-coding RNAs that are involved in the regulation of Sertoli cell function, spermatogenesis and germ cell apoptosis and (ii) alternative pre-mRNA splicing that affects the regulation of spermatogenesis but does not appear to affect germ cell apoptosis, at least during testis progression induced by undernutrition in the male sheep. These research outcomes can be extended to other animal models and are relevant to issues in human male fertility.

Reproduction (2017) 154 R133-R141
\end{abstract}

\section{Introduction}

In this review, we present advances in our basic understanding of testis function that have been revealed by studies of the effects of nutrition in sexually mature male sheep. The boundaries of the experimental model are important: changes in the level of nutrition can induce a reversible, non-pathological process that leads to changes in testis mass, sperm output and the efficiency of spermatogenesis. These responses are expressed under normal field conditions, either in relation to the annual forage cycle or in response to acute nutritional supplementation. The fact that the animals are postpubertal is critical because there is an inevitable focus on the function of Sertoli cells-cells that are thought to lose their ability to divide and become terminally differentiated at puberty. Finally, the model does not equate to fasting or to pathological effects caused by deficiencies in vitamins or trace elements, heavy metal toxicities or imbalances in essential amino or fatty acids. Rather, we constrain the model to variations in the amount of a balanced diet, using extremes that are similar in magnitude and duration to those that would be experienced by animals grazing natural forage (review: Martin et al. 1994b).

The neuroendocrine and endocrine processes through which nutrition affects reproductive function in this model have been explored in depth, and this work has been reviewed elsewhere (e.g., Martin et al. 1994b, Blache et al. 2003). In summary: (a) the responses involve metabolic inputs to the brain-gonadal axis (nutrients, metabolites, substrates) as well as endocrine signals from metabolic and storage tissues (leptin, insulin); (b) the metabolic and reproductive centres of the brain respond with changes in the output of gonadotrophinreleasing hormone $(\mathrm{GnRH})$, and thus, the secretion of gonadotrophins, inhibin and sex steroids; (c) testis mass also seems to be affected by processes that are independent of changes in GnRH secretion. Clearly, this endocrine context is critical when considering the cellular and molecular responses within the testis.

The mature male sheep and its responses to nutrition have a long history as a model for research into testis function. The first rigorous investigation was by 
Akira Mori who studied severely underfed rams in Japan during the Second World War. When his reports were published many years later (Mori 1959a,b), they showed that semen quality and sperm production were improved within a month or two by supplements of milk, pork and eggs! Subsequent studies included measures of testis mass, sperm output and 'spermatogenic efficiency', the number of sperm cells produced per unit mass of testis (Salamon 1964, Setchell et al. 1965, Braden et al. 1974, Oldham et al. 1978, Cameron et al. 1988, Guan et al. 2014b). The changes in spermatogenic efficiency are particularly relevant to the present review - for example, (Oldham et al. 1978) found that a $25 \%$ increase in testicular size led to an $81 \%$ increase in production of spermatozoa. Also important is the observation that it takes at least 7 weeks of nutritional treatment to affect the number of ejaculated spermatozoa (Parker \& Thwaites 1972), suggesting that spermatogenic efficiency is affected after the last spermatogonial division.

Using the classical measures of semen and sperm quality, it was found that the deleterious effects of undernutrition could be reversed by dietary supplementation (Mori 1959a, Salamon 1964, Tilton et al. 1964, Hiroe \& Tomizuka 1965, Parker \& Thwaites 1972) (Dana et al. 2000, Tufarelli et al. 2011). Not all studies agree (Fernandez et al. 2004) perhaps because the classical measures (sperm concentration, viability, morphology, subjective motility) lack accuracy and precision. Moreover, these techniques only assess the semen quality and do not address the quality of the spermatozoa. To resolve these issues, we used computer-assisted semen analysis and a sperm chromatin structure assay (Guan et al. 2014b). We found that sperm from rams that had been underfed for 65 days (testes regressing) swam with lower velocity and had more DNA damage than sperm from well-fed rams (testes growing). The amount of DNA damage was inversely correlated with change in testis mass, the percentage of motile sperm, and the numbers of sperm per gram of testis. It is therefore clear that, in adult rams, the effect of nutrition on spermatogenic efficiency is associated with a change in the quality of the spermatozoa as well as the number produced per day.

\section{The effect of nutrition on testis morphology}

Histological studies have shown that nutrition markedly affects the diameter of the seminiferous tubules, the relative proportion of testis occupied by the seminiferous tubules, the proportion of the seminiferous tubule occupied by the seminiferous epithelium, the relative proportion of interstitial tissue and the total volume of Leydig cells (Table 1). These observations were extended in a subsequent study (Guan et al. 2014a) that included the Johnsen Score, an indicator of spermatogenesis, again showing that spermatogenesis was impaired in underfed rams (testes regressing), but normal in both
Table 1 Morphometric analysis of the testicular tissue from mature male sheep ( $n=5$ per group) fed a supra-maintenance (high) or a sub-maintenance (low) diet for 69 days.

\begin{tabular}{lcc}
\hline Variable & High diet & Low diet \\
\hline Body weight $(\mathrm{kg})$ & $79 \pm 3$ & $48 \pm 4^{*}$ \\
Mean testis weight $(\mathrm{g})$ & $288 \pm 14$ & $117 \pm 10^{*}$ \\
Tubule diameter $(\mu \mathrm{m})$ & $229 \pm 6$ & $167 \pm 12^{*}$ \\
Lumen diameter $(\mu \mathrm{m})$ & $69 \pm 3$ & $66 \pm 7$ \\
Tubule length $(\mathrm{m})$ & $3503 \pm 104$ & $2378 \pm 329^{*}$ \\
Leydig cells $\left(\times 10^{8}\right)$ per testis & $75 \pm 8$ & $60 \pm 11$ \\
Sertoli cells $\left(\times 10^{8}\right)$ per testis & $120 \pm 5$ & $77 \pm 6.7^{*}$ \\
\hline
\end{tabular}

These data have been selected from the full set presented by Hötzel et al. (1998).

$* P<0.05$

maintenance-fed (testes stable) and well-fed rams (testes growing). The number of Leydig cells per testis was not affected by diet, but the total volume of Leydig cells was, indicating changes in the volume of individual cells. Due to the direct relationship between Leydig cells and testosterone secretion, therefore, an effect of diet on testosterone secretion and the peripheral concentrations of testosterone might be expected, and this is an important consideration because testosterone plays a major role in spermatogenesis. However, initial studies disagreed in terms of the outcome - for example, the early study showed a significant effect on testosterone secretion (Setchell et al. 1965) but recent work showed that nutritional treatments were not associated with changes in the amplitude of testosterone response to $\mathrm{LH}$ (Martin et al. 1994a). The disagreement could be due to differences between genotype, age or methodology, but the most likely explanation is the severity of the underfeeding (Hötzel et al. 1998).

\section{The effect of nutrition on Sertoli cell number}

Sertoli cells provide nutritional and structural support for germ cells and each Sertoli cell has a fixed capacity for the number of germ cells it can support (Sharpe et al. 2003); therefore, changes in production of spermatozoa may result from alterations in Sertoli cell number. This question was first addressed by Hötzel and coworkers (1998) who reported that total volume of Sertoli cell nuclei and the Sertoli cell number per testis were both higher in well-fed than in underfed adult Merino rams (Table 1). This finding might seem logical considering the differences in sperm production, but it contradicts the dogma that Sertoli cells stop proliferating at puberty, leaving the number fixed during adult life (Kluin et al. 1984, Monet-Kuntz et al. 1984, Hochereau-de Reviers et al. 1987). We therefore decided to repeat the study by using modern techniques (Guan et al. 2014a). We adopted GATA4 as a marker for Sertoli cells (Ketola et al. 2000) and combined stereological cell counts with the assessment of Sertoli cell activity by analysis of immunoreactivity to proliferation cell 
nuclear antigen. We found that there was no effect of nutritional treatment on Sertoli cell numbers, so the earlier observations of Hötzel and coworkers (1998) can be attributed to histological artefact, perhaps caused by effects of nutrition on Sertoli cell functionality (see below) that affected the ease and accuracy with which their nuclei could be counted. Interestingly, about $1 \%$ of Sertoli cells in all animals appeared to retain their ability to proliferate (Guan et al. 2014a). The possibility that Sertoli cells can proliferate after puberty suggests that, in future we might find ways to replenish damaged testes and restore germ cell production.

\section{The effect of nutrition on Sertoli cell function}

Around the onset of puberty, Sertoli cells undergo radical changes as they switch from an immature, proliferative state to a mature, non-proliferative state. Adjacent Sertoli cells form tight junctions with each other to create a unique adluminal compartment within which the meiotic and post-meiotic steps of spermatogenesis can proceed, as well as allowing formation of a fluidfilled lumen. As a result, the germ cells developing in the adluminal compartment are effectively sealed off from direct access to many nutrients, so the mature Sertoli cell takes on new functions that are lacking in fetal, proliferating Sertoli cells (McLaren et al. 1993).

In sexually mature sheep, we have shown that Sertoli cell function is clearly affected by nutritional treatment (Guan et al. 2014a), as evidenced by changes in molecular regulators of critical processes that are specific to Sertoli cells. Underfeeding-induced testis regression was associated with: (a) disrupted distribution of the tight junction protein CLDN11, increased expression of CLDN11 and decreased expression of zonula occludens protein 1 (ZO1); (b) reduced expression of GATA1, a marker for mature Sertoli cells (Beau et al. 2000), but an increase in the expression of $A M H$, a marker for immature Sertoli cells (Rey 1998), (Kliesch et al. 1998, Steger et al. 1999, Sharpe et al. 2003); (c) reduced expression of three Sertoli cell-specific genes (KLM, SOX9, MSI1). Therefore, in underfed rams experiencing a reduction in testis mass and spermatogenesis, it seems that tight junctions are degraded and differentiation and maturation are reversed in the Sertoli cells, reducing their efficiency as supporters of the germ cells. These observations are consistent with the reduction in the quality of ejaculated spermatozoa from the underfed rams.

\section{Effects of nutrition on small RNAs in the testis}

Small RNA molecules have recently emerged as potent regulators of gene expression at the post-transcriptional or translational level, with diverse biological outcomes (Plasterk 2006, Liang et al. 2014). There are three major categories of small RNAs: small interfering RNA (siRNA);
microRNA (miRNA) with about 22 nucleotides in singlestrand non-coding molecules and piwi-interacting RNA (piRNA). In this review, we will focus only on miRNAs and piRNAs where we have direct evidence for their roles in our model. MicroRNAs were discovered in 1993 in a nematode where they regulate the expression of complementary mRNA (Lee et al. 1993, Wightman et al. 1993). In 2011, miRNAs were also identified in mammals (Lagos-Quintana et al. 2001, Liang et al. 2015). miRNAs are highly conserved across species, and importantly, appear to regulate up to $30 \%$ of all genes in the human genome (Lewis et al. 2005). Thousands of miRNAs have now been discovered (miRBase Release 21.0, as of July, 2015, http://www.mirbase.org/index.shtml). The biogenesis of miRNAs is a multi-step process and has been well documented (Hutvagner et al. 2001, Kim et al. 2009, Liang et al. 2015), so will not be detailed here. The piRNAs form a relatively newly identified class of slightly longer molecules (26-32 nt) that bind to 'PIWI', a spermatogenesis-specific protein belonging to the Argonaute protein family (Aravin et al. 2006, Girard et al. 2006). The synthesis of piRNAs is not clear yet, although a 'ping pong' mechanism has been suggested (Liu et al. 2012). They are essential for germ cell maintenance and spermatogenesis in Drosophila and mammals (Thomson \& Lin 2009), and so are of interest in our quest to understand the effects of nutrition on spermatogenesis.

\section{Nutrition, miRNAs and spermatogenesis}

During spermatogenesis, the spatial and temporal regulation of gene expression is vitally important indeed, transcription is periodically silenced in germ cells by miRNAs (Papaioannou \& Nef 2010). The importance of miRNAs for spermatogenesis is also indicated by, for example, the infertility in male mice that follows removal of Dicer1, a gene necessary for the synthesis of miRNAs (Maatouk et al. 2008). Specifically, in Dicer1 knockout mice, only a few tubules contain elongating spermatids and any germ cells that did differentiate to elongating spermatids exhibited abnormal morphology and motility. Similar findings were reported in human (Hayashi et al. 2008).

It thus became clear that miRNAs could play a role in eliciting changes in spermatogenesis following a change in nutrition. We identified 44 miRNAs, including miR$10 \mathrm{~b}$ and miR-23b, which were differentially expressed in well-fed and underfed male sheep, and the predicted functions of these miRNAs were related to reproductive system development and sperm production and quality (Guan et al. 2015).

There is also a strong relationship between miRNAs and apoptosis - for example, three miRNAs (miR-15, miR-16, miR-31) are able to induce apoptosis by targeting the major anti-apoptotic factor, BCL2 (Cimmino et al. 2005, Korner et al. 2013). It has also become clear that apoptosis in male germ cells is regulated by 
miRNAs - for example, miR-34c was detected in mouse pachytene spermatocytes and highly expressed in spermatids; when it was silenced, the BCl-2/Bax ratio increased, preventing the induction of germ cell apoptosis by testosterone deprivation (Liang et al. 2012). In another study, transient inhibition of miR-21 in spermatogonial stem cell-enriched germ cell cultures increased the number of germ cells undergoing apoptosis (Niu et al. 2011).

Clearly, miRNAs could play a major role in germ cell apoptosis in the regressing testis of underfed rams. We found that 12 genes involved in apoptosis could be targeted by 9 miRNAs that were expressed differentially between well-fed and underfed sheep, with novelmiR-144 targeting four of the apoptosis-related genes (FASL, CASP3, BCL2L1, TP53; Guan et al. 2015). These findings led us to conclude that the decline in sperm production and sperm quality induced by undernutrition in the sexually mature sheep are mediated at least partly by increased apoptosis in germ cells, and this process is mediated by changes in the expression of miRNAs (Guan et al. 2015).

\section{piRNAs affect spermatogenesis}

A role for piRNAs in spermatogenesis is primarily supported by the functions of their partner Piwi proteins, including MIWI, MIWI2 and MILI, in stem cell self-renewal and the development of male germ cells (Cox et al. 1998). In MILI-knockout mice, spermatogenesis is disordered at the pachytene spermatocyte stage (Kuramochi-Miyagawa et al. 2004) and, in Miwi-deficient mice, no elongated spermatids or mature spermatozoa are observed (Deng \& Lin 2002).

To explore further the functions of piRNAs in spermatogenesis, undernutrition-induced testicular regression is an attractive experimental paradigm. We identified 35 putative piRNAs, including oar-piR-12568 and oar-piR-9006, which were differentially expressed in well-fed and underfed males and were associated with sperm production and quality (Guan et al. 2015). Interestingly, there was a positive correlation between the proportions of miRNAs and putative piRNAs in testicular tissue, for both underfed and well-fed males, indicating a synergistic relationship between these classes of small RNAs, a hypothesis that should be tested in further studies (Guan et al. 2015). Moreover, unlike the miRNAs, piRNAs are not conserved among species, so their functions in the sheep testis require further study.

\section{Effects of nutrition on alternative pre-mRNA splicing}

Alternative pre-mRNA splicing (AS) is an important mechanism for regulating gene expression and for increasing transcriptome plasticity and proteome diversity (Liang et al. 2016). It has been reported that around $60 \%$ of human gene products undergo alternative splicing (Modrek \& Lee 2002).

The process that generates alternative splicing has been reviewed in detail (Schwerk \& Schulze-Osthoff 2005), so will be addressed only briefly here. In a typical multiexon mRNA, the splicing pattern can be altered in many ways and, to date, eight types have been reported, of which the most common is a cassette exon that can be included in the mRNA or skipped, inserting or deleting a portion of internal sequence (Gurskaya et al. 2012). Two special cases of paired-cassette exons are mutually exclusive splicing (only one exon is included) and coordinate cassette exons (both exons are included). The fourth and fifth patterns are alternative $5^{\prime}$ or $3^{\prime}$ splice sites, in which exons can be extended or shortened in length (Fu et al. 1992). The sixth pattern is alternative first exon, in which transcriptional initiation at different promoters generates alternative 5 '-terminal exons that can be joined to a common 3' exon downstream (Mironov et al. 1999). Similarly, for the seventh pattern, alternative last exons, with alternative polyadenylation sites, can be joined to a common upstream exon (Wang et al. 2008). Finally, we have intron retention to leave the retained intronic sequence in the mRNA (Galante et al. 2004).

\section{Nutrition, alternative pre-mRNA splicing and spermatogenesis}

It has been reported that spermatogenesis is regulated by alternative pre-mRNA splicing that generates multiple transcript species from a common mRNA precursor. For example, some specific CREB mRNA isoforms generated by alternative splicing are expressed at a high level in the adult testis, and these isoforms are expressed after spermatogenesis has started (Ruppert et al. 1992). In addition, transcripts from several testis-specific genes that regulate gene expression are themselves alternatively spliced. For instance, a testis-specific splice of the Sry-related transcription factor, Sox17, which lacks the exon containing a single high mobility group box near the $\mathrm{NH}_{2}$-terminus, replaces the normal message during male meiosis, and results in an inactive $\mathrm{N}$-terminal truncation that lacks the DNA-binding domain in spermatids (Kanai et al. 1996). Another example is prolactin receptor, a pivotal factor for spermatogenesis in the mouse - one of its isoforms lacks two exons leading to downregulation of the expression of the full-length prolactin receptor, with the potential for explaining the role of prolactin in the annual cycles of testis growth in seasonal breeders such as red deer (Jabbour et al. 1998). These examples are probably the tip of an iceberg, and we expect many more candidates to be discovered experimentally by, for example, knockout of testis-specific splicing factors (Feng et al. 2002).

To date, very few studies have touched on the effects of environmental factors on alternative splicing within the testis and, again, undernutrition-induced testicular 
regression is an attractive experimental paradigm. In our transcriptome analysis in the testicular tissue from wellfed and underfed sheep, we found that nutrition did not affect the total number of alternative splicing junctions, but affected more than 200 alternative splicing events (Fig. 1). A total of 159 genes, including CREM and $D D X 4$, were differentially spliced between dietary treatments, with functions related to RNA splicing and spermatogenesis (Guan et al. 2017). Therefore, changes in alternative pre-mRNA splicing can help explain the effects on nutrition on spermatogenesis, but the effects of specific alternative types of splicing on spermatogenesis require further study.

\section{Nutrition, alternative pre-mRNA splicing and apoptosis}

Alternative splicing also plays a major role in the control of apoptosis, as evidenced by its effects on the expression of many of the proteins directly involved in the apoptotic pathways. Moreover, the proteins belonging to each family of apoptotic factors are alternatively spliced and, normally, the different isoforms produced in this process have distinct and even opposing functions during apoptosis. For example, by alternative splicing, C. elegans CED-4 is expressed in two isoforms, $C E D-4 L$ and $C E D-4 S$, that have opposite functions in apoptosis. Interestingly, splice site mutations in CED-4 lead to increased expression of anti-apoptotic CED-4L (Shaham \& Horvitz 1996). In addition, alternative splicing inhibits apoptosis by removing the intracellular domain and part of the extracellular domain from FasL (Ayroldi et al. 1999).

In the testes affected by nutrition, we explored alternative splicing events using RNA-Seq and found that the alternatively spliced genes that differed between underfed and well-fed sheep were not related to apoptosis (Guan et al. 2017), although one gene (HIPK3) was reported to be a member of a gene family that has been implicated in apoptosis. This result was surprising, because as indicated above, apoptosis is strongly associated with alternative splicing in other models in which nutrition was not the factor driving change in the testis. Clearly, the effects of nutrition need to be tested in other species.

\section{Extension to other species and human fertility}

The effect of nutrition on spermatogenesis has also been explored in other animal models and humans. For example, in a recent study of Holstein bulls, it was claimed that enhanced early-life nutrition increases sperm output potential without decreasing semen quality (Dance et al. 2016). Similarly, for the human, it was reported that sperm concentration, total sperm number, progressive motility were all positively associated with a healthy dietary pattern (Oostingh et al. 2017). This finding is supported by the positive correlations between the supplements of Vitamins D, B6 and B9 and sperm and semen parameters in humans (Abbasihormozi et al. 2017, Najafipour et al. 2017). It seems likely that changes in Sertoli cell function, such as those we have observed in the sheep, mediate such effects.

In recent years, there has been growing interest in the transgenerational effects of paternal malnutrition on subsequent offspring health, many of which are causally associated with epigenetic effects of nutrition on germ cells (Sinclair et al. 2016). Most intriguing in the context of the role of Sertoli cells is the finding that chronic paternal folate deficiency alters sperm DNA methylation and delays the onset of spermatogenesis, an effect associated with decreased pregnancy rates and birth defects (Bentivoglio et al. 1993, Lambrot et al. 2013). Such transgenerational effects suggest that nutritional factors alter the epigenetic landscape of sperm, leading to the transmission of altered epigenetic signatures to the next generation (Lambrot et al. 2013, Siklenka et al. 2015).

It is important to clarify the difference between wellfed animals that are the main focus of our studies and diet-induced obesity. In our studies, the animals were limited to a $10 \%$ increase in body weight over 3 months, similar to the normal annual pattern driven by the natural forage cycle (Martin et al. 1994b). Our animals never reached a body condition score that would be classified as 'obese', so cannot be compared to, for example, the extreme condition scores described by Zhu et al. (2010) or a human adult body mass index $>30$ (Centres for Disease Control and Prevention). Obesity in humans is associated with a decrease in male fertility as evidenced by the prevalence of artificial reproductive technologies (Sunderam et al. 2017). Many such patients have diabetes, a disease also linked to reduced sperm count and sperm motility and increased numbers of abnormal sperm. In one study, only $8.5 \%$ of diabetic patients had normal testis function (Inih et al. 2017). This phenomenon seems to apply across species because similar outcomes are observed in mice, with male obesity altering sperm microRNA content (Ghanayem et al. 2010, Fullston et al. 2016). The adipose-tissue hormone, leptin, might play a role in obesity-induced male infertility or subfertility (Barash et al. 1996), perhaps through effects on Sertoli cell acetate production and thus the nutritional support of spermatogenesis (Martins et al. 2015). In our sheep model, the dietary treatments are relatively mild but nevertheless affect circulating leptin concentrations (Blache et al. 2003), suggesting the need to investigate this mechanism.

Finally, we need to remember that males rarely live in an environment where only one factor varies (Martin et al. 1994b). In addition to variation in nutrition, freeranging animals are often confronted with stressors that will likely affect Sertoli cell function. In mice, for example, it has been shown that heat stress induces germ cell apoptosis and chronic restraint stress 


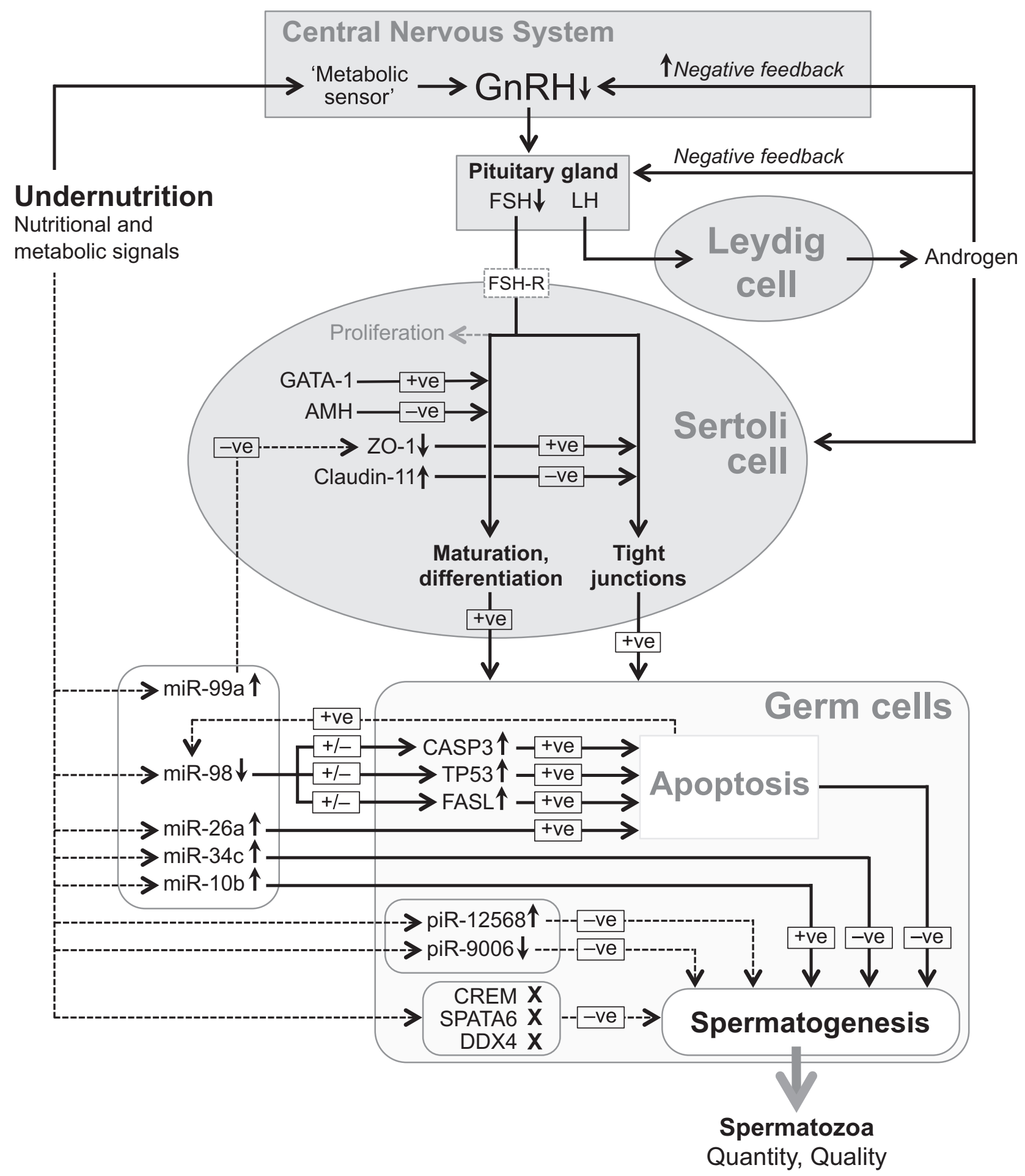

Figure 1 A working hypothesis of the mechanisms through which undernutrition affects testis function in the sexually mature sheep, indicating roles could be played by small, non-coding RNAs. Stimulation is indicated by '+ve' and inhibition is indicated by '-ve'. Effects mediated by regulatory factors are indicated by vertical arrows, and effects mediated by alternative RNA splicing are indicated by ' $\mathrm{X}$ '. Solid lines denote pathways supported by strong evidence, whereas broken lines indicate pathways where the evidence is still accumulating. Nutritional and metabolic signals do not seem to affect the proliferation of Sertoli cells but they do affect Sertoli cell function, notably the organization of tight junctions and cellular maturation. The Sertoli cell responses, combined with nutrition-induced changes in germ cell apoptosis, affect the quantity and quality of spermatozoa produced. Modified from Guan et al. (2015). 
decreases testosterone secretion (Lopez-Calderon et al. 1991, Yin et al. 1997, Paul et al. 2009). Similar findings have been reported for the human (Fenster et al. 1997, Clarke et al. 1999).

\section{Conclusions and future directions}

In sexually mature male sheep, the loss of testis mass and reductions in sperm production, sperm quality and spermatogenic efficiency caused by mild undernutrition are not accompanied by changes in Sertoli cell number, although a few Sertoli cells do appear to retain proliferative ability after puberty. On the other hand, testis regression is associated with disruption of Sertoli cell function, including a loss of tight junction integrity and reversal of differentiation and maturation. These effects would be expected to reduce the nutritional and structural support for the developing germ cells, thus explaining, at least partially, the increase in germ cell apoptosis and reduction in spermatogenesis, two contributors to spermatogenic efficiency. These outcomes seem to be mediated by changes in two RNAbased processes: the expression of small non-coding RNAs that are involved in the regulation of Sertoli cell function, spermatogenesis and germ cell apoptosis, and alternative pre-mRNA splicing that affects regulation of spermatogenesis but does not appear to affect germ cell apoptosis, at least during testis regression induced by mild undernutrition in the male sheep.

Our observations of nutritional effects on spermatogenesis in the sheep need to be confirmed in other animal models, such as the mouse, if only because ruminants and monogastrics might be expected to differ significantly in their physiological responses to nutritional treatments. Moreover, piRNAs are not conserved among species so the changes that we observed require further study. In addition, our profiling of small RNAs and the transcriptome, and our observations of the relationship between RNA expression and protein function, need to be tested in other models. Finally, we need to test whether the molecular mechanisms that are responsible for the reversible and non-pathological change in testis function induced by under-nutrition in male sheep can be applied to other environmental challenges or pathological disruptions of sperm production. On the other hand, the differentially expressed miRNA (novelmiR-144), the differentially spliced genes (CREM and $D D X 4)$, and the testis phenotype related genes (CFLAR, PTPRC) that we have identified in sheep could be potential biomarkers for apoptosis and spermatogenesis in humans. The predicted functions of these genes need to be verified using in vivo and in vitro experimentation.

\section{Declaration of interest}

The authors declare that there is no conflict of interest that could be perceived as prejudicing the impartiality of this review.

\section{Funding}

Yongjuan Guan was financially supported by a Scholarship for International Research Fees from the University of Western Australia.

\section{Acknowledgements}

The authors thank Dr John Milton (University of Western Australia) for designing the nutritional treatments, and Dr Irek Malecki and Dr Penny Hawken for their scientific contributions to the experimental work. We are grateful to Dr Leluo Guan and Dr Guanxiang Liang for their help in high-throughput sequencing and bioinformatics analysis. We thank Dr Sarah Meachem (MIMR-PHI Institute of Medical Research) and Tom Stewart for their guidance of histology work. We would like to thank Dr Cesar Rosales Nieto, Mr Gary Cass, Mrs Margaret Blackberry, Dr Trina Jorre de St Jorre and Mr Fahad Almohsen for their help in tissue collection and preservation.

\section{References}

Abbasihormozi S, Kouhkan A, Alizadeh AR, Shahverdi AH, Nasr-Esfahani MH, Sadighi Gilani MA, Salman Yazdi R, Matinibehzad A \& Zolfaghari Z 2017 Association of vitamin D status with semen quality and reproductive hormones in Iranian subfertile men. Andrology 5 113-118. (doi:10.1111/andr.12280)

Aravin A, Gaidatzis D, Pfeffer S, Lagos-Quintana M, Landgraf P, lovino N, Morris P, Brownstein MJ, Kuramochi-Miyagawa S, Nakano T et al. 2006 A novel class of small RNAs bind to MILI protein in mouse testes. Nature 442 203-207. (doi:10.1038/nature04916)

Ayroldi E, D'Adamio F, Zollo O, Agostini M, Moraca R, Cannarile L, Migliorati G, Delfino DV \& Riccardi C 1999 Cloning and expression of a short Fas ligand: a new alternatively spliced product of the mouse Fas ligand gene. Blood 94 3456-3467.

Barash IA, Cheung CC, Weigle DS, Ren H, Kabigting EB, Kuijper JL, Clifton DK \& Steiner RA 1996 Leptin is a metabolic signal to the reproductive system. Endocrinology 137 3144-3147. (doi:10.1210/ endo.137.7.8770941)

Beau C, Rauch M, Joulin V, Jegou B \& Guerrier D 2000 GATA-1 is a potential repressor of anti-Mullerian hormone expression during the establishment of puberty in the mouse. Molecular Reproduction and Development 56 124-138. (doi:10.1002/(SICl)1098-2795(200006)56:2<124::AIDMRD2>3.0.CO;2-J)

Bentivoglio G, Melica F \& Cristoforoni P 1993 Folinic acid in the treatment of human male infertility. Fertility and Sterility 60 698-701. (doi:10.1016/ S0015-0282(16)56225-6)

Blache D, Zhang S \& Martin GB 2003 Fertility in male sheep: modulators of the acute effects of nutrition on the reproductive axis of male sheep. Reproduction 61 387-402.

Braden AWH, Turnbull KE, Mattner PE \& Moule GR 1974 Effect of protein and energy content of the diet on the rate of sperm production in rams. Australian Journal of Biological Sciences 27 67-73.

Cameron AWN, Murphy PM \& Oldham CM 1988 Nutrition of rams and output of spermatozoa. Proceedings of the Australian Society of Animal Production 17 162-165.

Cimmino A, Calin GA, Fabbri M, lorio MV, Ferracin M, Shimizu M, Wojcik SE, Aqeilan RI, Zupo S, Dono M et al. 2005 miR-15 and miR-16 induce apoptosis by targeting BCL2. PNAS 102 13944-13949. (doi:10.1073/ pnas.0506654102)

Clarke RN, Klock SC, Geoghegan A \& Travassos DE 1999 Relationship between psychological stress and semen quality among in-vitro fertilization patients. Human Reproduction 14 753-758. (doi:10.1093/ humrep/14.3.753)

Cox DN, Chao A, Baker J, Chang L, Qiao D \& Lin H 1998 A novel class of evolutionarily conserved genes defined by piwi are essential for stem cell self-renewal. Genes and Development 12 3715-3727.

Dana N, Tegegneb A \& Shenkorua T 2000 Feed intake, sperm output and seminal characteristics of Ethiopian highland sheep supplemented with different levels 
of leucaena (Leucaena leucocephala) leaf hay. Animal Feed Science and Technology 86 239-249. (doi:10.1016/S0377-8401(00)00152-8)

Dance A, Thundathil J, Blondin P \& Kastelic J 2016 Enhanced early-life nutrition of Holstein bulls increases sperm production potential without decreasing postpubertal semen quality. Theriogenology 86 687.e682-694. e682. (doi:10.1016/j.theriogenology.2016.02.022)

Deng W \& Lin H 2002 miwi, a murine homolog of piwi, encodes a cytoplasmic protein essential for spermatogenesis. Developmental Cell 2 819-830. (doi:10.1016/S1534-5807(02)00165-X)

Feng LX, Chen Y, Dettin L, Pera RA, Herr JC, Goldberg E \& Dym M 2002 Generation and in vitro differentiation of a spermatogonial cell line. Science 297 392-395. (doi:10.1126/science.1073162)

Fenster L, Katz DF, Wyrobek AJ, Pieper C, Rempel DM, Oman D \& Swan SH 1997 Effects of psychological stress on human semen quality. Journal of Andrology 18 194-202.

Fernandez M, Giraldez FJ, Frutos P, Lavin P \& Mantecon AR 2004 Effect of undegradable protein supply on testicular size, spermiogram parameters and sexual behavior of mature Assaf rams. Theriogenology 62 299-310. (doi:10.1016/j.theriogenology.2003.10.003)

Fu XD, Mayeda A, Maniatis T \& Krainer AR 1992 General splicing factors SF2 and SC35 have equivalent activities in vitro, and both affect alternative $5^{\prime}$ and $3^{\prime}$ splice site selection. PNAS 89 11224-11228. (doi:10.1073/pnas.89.23.11224)

Fullston T, Ohlsson-Teague EM, Print CG, Sandeman LY \& Lane M 2016 Sperm microRNA content is altered in a mouse model of male obesity but the same suite of microRNAs are not altered in offspring's sperm. PLOS ONE 11 e0166076. (doi:10.1371/journal.pone.0166076)

Galante PA, Sakabe NJ, Kirschbaum-Slager N \& de Souza SJ 2004 Detection and evaluation of intron retention events in the human transcriptome. RNA 10 757-765. (doi:10.1261/rna.5123504)

Ghanayem BI, Bai R, Kissling GE, Travlos G \& Hoffler U 2010 Diet-induced obesity in male mice is associated with reduced fertility and potentiation of acrylamide-induced reproductive toxicity. Biology of Reproduction $\mathbf{8 2}$ 96-104. (doi:10.1095/biolreprod.109.078915)

Girard A, Sachidanandam R, Hannon GJ \& Carmell MA 2006 A germlinespecific class of small RNAs binds mammalian Piwi proteins. Nature 442 199-202. (doi:10.1038/nature04917)

Guan Y, Liang G, Hawken PA, Meachem SJ, Malecki IA, Ham S, Stewart T, Guan le L \& Martin GB 2014a Nutrition affects Sertoli cell function but not Sertoli cell numbers in sexually mature male sheep. Reproduction Fertility and Development 28 1152-1163. (doi:10.1071/RD14368)

Guan Y, Malecki IA, Hawken PA, Linden MD \& Martin GB 2014b Under-nutrition reduces spermatogenic efficiency and sperm velocity, and increases sperm DNA damage in sexually mature male sheep. Animal Reproduction Science 149 163-172. (doi:10.1016/j. anireprosci.2014.07.014)

Guan Y, Liang G, Hawken PA, Malecki IA, Cozens G, Vercoe PE, Martin GB \& Guan le L 2015 Roles of small RNAs in the effects of nutrition on apoptosis and spermatogenesis in the adult testis. Scientific Reports $\mathbf{5}$ 10372 . (doi:10.1038/srep10372)

Guan Y, Liang G, Martin GB \& Guan LL 2017 Functional changes in mRNA and alternative pre-mRNA splicing associated with the effects of nutrition on apoptosis and spermatogenesis in the adult testis. BMC Genomics 18 64. (doi:10.1186/s12864-016-3385-8)

Gurskaya NG, Staroverov DB, Zhang L, Fradkov AF, Markina NM, Pereverzev AP \& Lukyanov KA 2012 Analysis of alternative splicing of cassette exons at single-cell level using two fluorescent proteins. Nucleic Acids Research 40 e57. (doi:10.1093/nar/gkr1314)

Hayashi K, Chuva de Sousa Lopes SM, Kaneda M, Tang F, Hajkova P, Lao K, O'Carroll D, Das PP, Tarakhovsky A, Miska EA et al. 2008 MicroRNA biogenesis is required for mouse primordial germ cell development and spermatogenesis. PLOS ONE 3 e1738. (doi:10.1371/journal.pone.0001738)

Hiroe K \& Tomizuka T 1965 Effects of nutrition on the characteristics of goat semen. Bulletin of the National Institute of Animal Industries 8 17-24.

Hochereau-de Reviers MT, Monet-Kuntz C \& Courot M 1987 Spermatogenesis and Sertoli cell numbers and function in rams and bulls. Journal of Reproduction and Fertility Supplement 34 101-114.

Hötzel MJ, Markey CM, Walkden-Brown SW, Blackberry MA \& Martin GB 1998 Morphometric and endocrine analyses of the effects of nutrition on the testis of mature Merino rams. Journal of Reproduction and Fertility 113 217-230.

Hutvagner G, McLachlan J, Pasquinelli AE, Balint E, Tuschl T \& Zamore PD 2001 A cellular function for the RNA-interference enzyme Dicer in the maturation of the let-7 small temporal RNA. Science 293 834-838. (doi:10.1126/science.1062961)

Inih OS, Esther YE, Adetola FO, Chinedu AA, Brenda NC \& Efedaye OA 2017 Testicular dysfunction is a common feature in men with type2 diabetes mellitus in a Nigerian tertiary hospital. Current Diabetes Reviews 13 (in press). (doi:10.2174/1573399813666170425152046)

Jabbour HN, Clarke LA, BramleyT, Postel-Vinay MC, Kelly PA \& Edery M 1998 Alternative splicing of the prolactin receptor gene generates a 1.7 kb RNA transcript that is linked to prolactin function in the red deer testis. Journal of Molecular Endocrinology 21 51-59. (doi:10.1677/jme.0.0210051)

Kanai Y, Kanai-Azuma M, Noce T, Saido TC, Shiroishi T, Hayashi Y \& Yazaki K 1996 Identification of two Sox17 messenger RNA isoforms, with and without the high mobility group box region, and their differential expression in mouse spermatogenesis. Journal of Cell Biology 133 667-681. (doi:10.1083/jcb.133.3.667)

Ketola I, Pentikainen V, Vaskivuo T, Ilvesmaki V, Herva R, Dunkel L, Tapanainen JS, Toppari J \& Heikinheimo M 2000 Expression of transcription factor GATA-4 during human testicular development and disease. Journal of Clinical Endocrinology and Metabolism 85 3925-3931. (doi:10.1210/jcem.85.9.6828)

Kim VN, Han J \& Siomi MC 2009 Biogenesis of small RNAs in animals. Nature Reviews Molecular Cell Biology 10 126-139. (doi:10.1038/nrm2632)

Kliesch S, Behre HM, Hertle L \& Bergmann M 1998 Alteration of Sertoli cell differentiation in the presence of carcinoma in situ in human testes. Journal of Urology 160 1894-1898. (doi:10.1016/S00225347(01)62439-X)

Kluin PM, Kramer MF \& de Rooij DG 1984 Proliferation of spermatogonia and Sertoli cells in maturing mice. Anatomy and Embryology 169 73-78. (doi:10.1007/BF00300588)

Korner C, Keklikoglou I, Bender C, Worner A, Munstermann E \& Wiemann S 2013 MicroRNA-31 sensitizes human breast cells to apoptosis by direct targeting of protein kinase C epsilon (PKCepsilon). Journal of Biological Chemistry 288 8750-8761. (doi:10.1074/jbc.M112.414128)

Kuramochi-Miyagawa S, Kimura T, Ijiri TW, Isobe T, Asada N, Fujita Y, Ikawa M, Iwai N, Okabe M, Deng W et al. 2004 Mili, a mammalian member of piwi family gene, is essential for spermatogenesis. Development 131 839-849. (doi:10.1242/dev.00973)

Lagos-Quintana M, Rauhut R, Lendeckel W \& Tuschl T 2001 Identification of novel genes coding for small expressed RNAs. Science 294 853-858. (doi:10.1126/science.1064921)

Lambrot R, Xu C, Saint-Phar S, Chountalos G, Cohen T, Paquet M, Suderman M, Hallett M \& Kimmins S 2013 Low paternal dietary folate alters the mouse sperm epigenome and is associated with negative pregnancy outcomes. Nature Communications 4 2889. (doi:10.1038/ ncomms3889)

Lee RC, Feinbaum RL \& Ambros V 1993 The C. elegans heterochronic gene lin-4 encodes small RNAs with antisense complementarity to lin-14. Cell 75 843-854. (doi:10.1016/0092-8674(93)90529-Y)

Lewis BP, Burge CB \& Bartel DP 2005 Conserved seed pairing, often flanked by adenosines, indicates that thousands of human genes are microRNA targets. Cell 120 15-20. (doi:10.1016/j.cell.2004.12.035)

Liang X, Zhou D, Wei C, Luo H, Liu J, Fu R \& Cui S 2012 MicroRNA-34C enhances murine male germ cell apoptosis through targeting ATF1. PLOS ONE 7 e33861. (doi:10.1371/journal.pone.0033861)

Liang G, Malmuthuge N, McFadden TB, Bao H, Griebel PJ, Stothard P \& Guan le L 2014 Potential regulatory role of microRNAs in the development of bovine gastrointestinal tract during early life. PLOS ONE 9 e92592. (doi:10.1371/journal.pone.0092592)

Liang G, Malmuthuge N, Guan le L \& Griebel P 2015 Model systems to analyze the role of miRNAs and commensal microflora in bovine mucosal immune system development. Molecular Immunology 66 57-67. (doi:10.1016/j.molimm.2014.10.014)

Liang G, Malmuthuge N, Guan Y, Ren Y, Griebel PJ \& Guan le L 2016 Altered microRNA expression and pre-mRNA splicing events reveal new mechanisms associated with early stage Mycobacterium avium subspecies paratuberculosis infection. Scientific Reports 624964. (doi:10.1038/srep24964)

Liu G, Lei B, Li Y, Tong K, Ding Y, Luo L, Xia X, Jiang S, Deng C, Xiong Y et al. 2012 Discovery of potential piRNAs from next generation sequences of the sexually mature porcine testes. PLOS ONE 7 e34770. (doi:10.1371/ journal.pone.0034770)

Lopez-Calderon A, Ariznavarreta C, Gonzalez-Quijano MI, Tresguerres JA \& Calderon MD 1991 Stress induced changes in testis function. 
Journal of Steroid Biochemistry and Molecular Biology 40 473-479. (doi:10.1016/0960-0760(91)90217-S)

Maatouk DM, Loveland KL, McManus MT, Moore K \& Harfe BD 2008 Dicer1 is required for differentiation of the mouse male germline. Biology of Reproduction 79 696-703. (doi:10.1095/biolreprod.108.067827)

Martin GB, Tjondronegoro S \& Blackberry MA 1994a Effects of nutrition on testicular size and the concentrations of gonadotrophins, testosterone and inhibin in plasma of mature male sheep. Journal of Reproduction and Fertility 101 121-128. (doi:10.1530/jrf.0.1010121)

Martin GB, Walkden-Brown SW, Boukhliq R, Tjondronegoro S, Miller DW, Fisher JS, Hötzel MJ, Restall BJ \& Adams NR 1994b Non-photoperiodic inputs into seasonal breeding in male ruminants. In Perspectives in Comparative Endocrinology, pp 574-585. Eds KG Davey, RE Peter \& SS Tobe. Ottawa: National Research Council of Canada.

Martins AD, Moreira AC, Sa R, Monteiro MP, Sousa M, Carvalho RA, Silva BM, Oliveira PF \& Alves MG 2015 Leptin modulates human Sertoli cells acetate production and glycolytic profile: a novel mechanism of obesity-induced male infertility? Biochimica et Biophysica Acta 1852 1824-1832. (doi:10.1016/j.bbadis.2015.06.005)

McLaren TT, Foster PM \& Sharpe RM 1993 Effect of age on seminiferous tubule protein secretion and the adverse effects of testicular toxicants in the rat. International Journal of Andrology 16 370-379. (doi:10.1111/j.1365-2605.1993.tb01364.x)

Mironov AA, Fickett JW \& Gelfand MS 1999 Frequent alternative splicing of human genes. Genome Research 9 1288-1293. (doi:10.1101/gr.9.12.1288)

Modrek B \& Lee C 2002 A genomic view of alternative splicing. Nature Genetics 30 13-19. (doi:10.1038/ng0102-13)

Monet-Kuntz C, Hochereau-de Reviers MT \& Terqui M 1984 Variations in testicular androgen receptors and histology of the lamb testis from birth to puberty. Journal of Reproduction and Fertility 70 203-210. (doi:10.1530/jrf.0.0700203)

Mori A 1959a Studies on the reproductive failure of ram caused by underfeeding. I. On the effects of underfeeding upon the mating potency of ram, and the effects of normal feeding upon its recovery from impotence. Tohoku Journal of Agricultural Research $10263-281$.

Mori A $1959 b$ Studies on the reproductive failure of ram caused by underfeeding. II. On the effects of feeding milk, pork and eggs to impotent ram. Tohoku Journal of Agricultural Research 10 283-288.

Najafipour R, Moghbelinejad S, Aleyasin A \& Jalilvand A 2017 Effect of B9 and B12 vitamin intake on semen parameters and fertility of men with MTHFR polymorphisms. Andrology 5 704-710. (doi:10.1111/andr.12351)

Niu Z, Goodyear SM, Rao S, Wu X, Tobias JW, Avarbock MR \& Brinster RL 2011 MicroRNA-21 regulates the self-renewal of mouse spermatogonial stem cells. PNAS 108 12740-12745. (doi:10.1073/pnas.1109987108)

Oldham CM, Adams NR, Gherardi PB, Lindsay DR \& Mackintosh JB 1978 The influence of level of feed intake on sperm-producing capacity of testicular tissue in the ram. Australian Journal of Agricultural Research 29 173-179. (doi:10.1071/AR9780173)

Oostingh EC, Steegers-Theunissen RP, de Vries JH, Laven JS \& Koster MP 2017 Strong adherence to a healthy dietary pattern is associated with better semen quality, especially in men with poor semen quality. Fertility and Sterility $\mathbf{1 0 7}$ 916.e912-923.e912. (doi:10.1016/j. fertnstert.2017.02.103)

Papaioannou MD \& Nef S 2010 microRNAs in the testis: building up male fertility. Journal of Andrology 31 26-33. (doi:10.2164/ jandrol.109.008128)

Parker GV \& Thwaites CJ 1972 The effects of undernutrition on libido and semen quality in adult Merino rams. Australian Journal of Agricultural Research 23 109-115. (doi:10.1071/AR9720109)

Paul C, Teng S \& Saunders PT 2009 A single, mild, transient scrotal heat stress causes hypoxia and oxidative stress in mouse testes, which induces germ cell death. Biology of Reproduction 80 913-919. (doi:10.1095/ biolreprod.108.071779)

Plasterk RH 2006 Micro RNAs in animal development. Cell 124 877-881. (doi:10.1016/j.cell.2006.02.030)

Rey R 1998 Endocrine, paracrine and cellular regulation of postnatal antimullerian hormone secretion by sertoli cells. Trends in Endocrinology and Metabolism 9 271-276. (doi:10.1016/S1043-2760(98)00069-1)

Ruppert S, Cole TJ, Boshart M, Schmid E \& Schutz G 1992 Multiple mRNA isoforms of the transcription activator protein CREB: generation by alternative splicing and specific expression in primary spermatocytes. EMBO Journal 11 1503-1512.
Salamon S 1964 The effect of nutritional regimen on the potential semen production of rams. Australian Journal of Agricultural Research 15 645-656. (doi:10.1071/AR9640645)

Schwerk C \& Schulze-Osthoff K 2005 Regulation of apoptosis by alternative pre-mRNA splicing. Molecular Cell 19 1-13. (doi:10.1016/j. molcel.2005.05.026)

Setchell BP, Waites GM \& Lindner HR 1965 Effect of undernutrition on testicular blood flow and metabolism and the output of testosterone in the ram. Journal of Reproduction and Fertility 9 149-162. (doi:10.1530/ jrf.0.0090149)

Shaham S \& Horvitz HR 1996 An alternatively spliced C. elegans ced-4 RNA encodes a novel cell death inhibitor. Cell 86 201-208. (doi:10.1016/ S0092-8674(00)80092-6)

Sharpe RM, McKinnell C, Kivlin C \& Fisher JS 2003 Proliferation and functional maturation of Sertoli cells, and their relevance to disorders of testis function in adulthood. Reproduction 125 769-784. (doi:10.1530/ rep.0.1250769)

Siklenka K, Erkek S, Godmann M, Lambrot R, McGraw S, Lafleur C, Cohen T, Xia J, Suderman M, Hallett M et al. 2015 Disruption of histone methylation in developing sperm impairs offspring health transgenerationally. Science 350 aab2006. (doi:10.1126/science.aab2006)

Sinclair KD, Rutherford KM, Wallace JM, Brameld JM, Stoger R, Alberio R, Sweetman D, Gardner DS, Perry VE, Adam CL et al. 2016 Epigenetics and developmental programming of welfare and production traits in farm animals. Reproduction Fertility and Development. 28 1443-1478. (doi:10.1071/RD16102)

Steger K, Rey R, Louis F, Kliesch S, Behre HM, Nieschlag E, Hoepffner W, Bailey D, Marks A \& Bergmann M 1999 Reversion of the differentiated phenotype and maturation block in Sertoli cells in pathological human testis. Human Reproduction 14 136-143. (doi:10.1093/ humrep/14.1.136)

Sunderam S, Kissin DM, Crawford SB, Folger SG, Jamieson DJ, Warner L \& Barfield WD 2017 Assisted reproductive technology surveillance: United States, 2014. MMWR Surveillance Summaries 66 1-24. (doi:10.15585/ mmwr.ss6606a1)

Thomson T \& Lin H 2009 The biogenesis and function of PIWI proteins and piRNAs: progress and prospect. Annual Review of Cell and Developmental Biology 25 355-376. (doi:10.1146/annurev.cellbio.24.110707.175327)

Tilton WA, Warnick AC, Cunha TJ, Loggins PE \& Shirley RL 1964 Effect of low energy and protein intake on growth and reproductive performance of young rams. Journal of Animal Science 23 645-650. (doi:10.2527/ jas1964.233645x)

Tufarelli V, Lacalandra GM, Aiudi G, Binetti F \& Laudadio V 2011 Influence of feeding level on live body weight and semen characteristics of Sardinian rams reared under intensive conditions. Tropical Animal Health and Production 43 339-345. (doi:10.1007/s11250-010-9695-y)

Wang ET, Sandberg R, Luo S, Khrebtukova I, Zhang L, Mayr C, Kingsmore SF, Schroth GP \& Burge CB 2008 Alternative isoform regulation in human tissue transcriptomes. Nature 456 470-476. (doi:10.1038/ nature07509)

Wightman B, Ha I \& Ruvkun G 1993 Posttranscriptional regulation of the heterochronic gene lin-14 by lin- 4 mediates temporal pattern formation in C. elegans. Cell 75 855-862. (doi:10.1016/00928674(93)90530-4)

Yin Y, Hawkins KL, DeWolf WC \& Morgentaler A 1997 Heat stress causes testicular germ cell apoptosis in adult mice. Journal of Andrology $\mathbf{1 8}$ 159-165.

Zhu MJ, Du M, Nathanielsz PW \& Ford SP 2010 Maternal obesity upregulates inflammatory signaling pathways and enhances cytokine expression in the mid-gestation sheep placenta. Placenta 31 387-391. (doi:10.1016/j.placenta.2010.02.002)

Received 2 February 2017

First decision 28 February 2017

Revised manuscript received 20 August 2017

Accepted 29 August 2017 